\title{
Hukum Minimum Liebig - Sebuah Ulasan dan Aplikasi Dalam Biologi Kontemporer
}

\author{
Wendy Achmmad Mustaqim a* \\ ${ }^{a}$ Program Studi Biologi Tumbuhan, Sekolah Pascasarjana, Institut Pertanian Bogor, Bogor, Jawa Barat-Indonesia \\ *Email: wendyachmmadm@gmail.com \\ Diterima (received) 28 Agustus 2017; disetujui (accepted) 1 Februari 2018; tersedia secara online (available online) 1 Februari 2018
}

\begin{abstract}
Optimum plant growth depends on numerous ecological factors. In relation to this theme, there is an old law called Law of the Minimum Liebig. The postulate discussed the growth of the plant that is determined by the scarcest environmental factors. It is one of the oldest ecological postulate proposed more than one and a half-century ago. It has become one of the most important foundations for agriculture and biology, even the in contemporary biology. This short review will provide the history, principles, development and criticism, and applications in some recent biological sciences, including evolution, conservation, ecological indicator and even climate change.
\end{abstract}

Keywords: law of the minimum; Liebig's law; climate change; conservation; evolution

\section{Pendahuluan}

Tumbuhan di alam menghadapi berbagai macam faktor ekologi, mulai dari biotik dan abiotik. Di dalam tumbuh kembangnya, optimalitas tumbuhan dipengaruhi oleh tingkat keberadaan faktor-faktor ekologis tersebut. Faktor-faktor tersebut memiliki kisaran optimum pada tiap tumbuhan dan pada kondisi tertentu dapat menjadi faktor pembatas (Setiadi dan Tjondronegoro, 1989). Di dalam ekologi, termasuk di dalam ekologi tumbuhan, salah satu aspek yang dibahas adalah mengenai hukum minimum Liebig yang membahas mengenai kondisi minimum faktor atau sumber daya di habitat tumbuh. Hukum yang digagas oleh ahli kimia organik Jerman pada sekitar pertengahan abad ke-18 ini menjadi dasar perkembangan ekologi, pertanian dan ilmu-ilmu terkait lainnya. Jarang diuraikan kembali pada buku-buku teks ekologi yang relatif baru, sebuah ulasan untuk mengetahui sejarah dan perkembangan berikut aplikasinya adalah suatu yang cukup penting untuk dibuat.

\section{Sejarah Singkat, Definisi dan Perkembangan}

Pada tahun 1840, Justus von Liebig, seorang ahli kimia organik berkebangsaan Jerman ini mempublikasikan buku berjudul Organic chemistry in its applications to agriculture and physiology (von Liebig dan Playfair, 1840) dan versi bahasa Jerman, Die organische chemie in ibrer unwendung auf agricultur und physiologie von Liebig (1841). Di dalam buku tersebut, Liebig membahas berbagai hal terkait fisiologi dan agrikultur, dan salah satu yang terpenting adalah apa yang saat ini kita kenal sebagai hukum minimum Liebig.

Liebig di dalam buku tersebut, memberikan pandangan yang berlaku umum saat itu tentang teori humus. Ia menyatakan bahwa mineral diperlukan dari tanah dan berbagai gas dari udara $(\mathrm{CO} 2)$ atau air $(\mathrm{H}$ dan O2).Termasuk dalam bahasan Liebig adalah nitrogen, yang menurut Liebig diambil dari udara. Untuk yang terakhir, pemikiran Liebig tidak berlaku pada sebagian besar tumbuhan, kecuali pada tumbuhan penambat nitrogen dari famili Fabaceae. Berdasarkan pemikian tersebut, Liebig berhasil mengungkapkan bahwa nutrien di tanah yang telah diambil oleh tumbuhan dapat digantikan dengan pemberian pupuk (Barak, 2000).

doi: https://doi.org/10.24843/blje.2018.v18.i01.p04 
Liebig memberikan uraian bahwa pertumbuhan suatu tumbuhan, yang dicontohkan pada gandum (Triticum), tidak akan tumbuh optimal pada tanah pasir atau tanah berkarbonat tinggi. Liebig lebih lanjut mengatakan bahwa ketiadaan kekurangan unsur tertentu (alkali) menjadi penyebab tumbuhan tersebut tidak tumbuh optimal. Hal ini terjadi meskipun substansi lain yang diperlukan pada habitat tumbuh tersebut ditemukan dalam jumlah banyak. Ia juga menggambarkan bagaimana tumbuhan musiman yang berganti daun tiap tahunnya tidak dapat tumbuh pada habitat tanah pasir dan batuan kapur di Pegunungan Carphatian, Semenanjung Balkan, Eropa bagian timur. Diketahui bahwa tumbuhan musiman memerlukan banyak ion alkali, yang notabene sedikit di tanah pasir dan kapur, tidak banyak tumbuh di tempat tersebut. Hal yang berbeda dengan kelompok tumbuhan selalu hijau dari genus Abies (Pinaceae) (von Liebig dan Playfair, 1840).

Seiring dengan waktu, pernyataan tersebut banyak dikutip dan sering disederhanakan menjadi suatu hukum yang menyatakan bahwa pertumbuhan tanaman dipengaruhi dan ditentukan oleh unsur yang jumlahnya paling rendah (Odum, 1975; Setiadi dan Tjondronegoro, 1989) dan hasil pertumbuhan, dalam hal ini diaplikasikan pada pertanian, dapat ditingkatkan dengan memperbaiki faktor yang pembatas minimum tersebut (Wallace, 1993). Konsep inilah yang kita kenal dengan hukum minimum Liebig.

Sekitar satu setengah abad setelah kemunculannya, terdapat sebuah catatan penting yang dibuat oleh para ilmuan terkait hukum ini. Setelah diakui begitu lama bahwa Liebig adalah penemu hukum ini, van der Ploeg et al. (1999) mengusulkan bahwa Liebig bukanlah orang yang sepenuhnya menyimpulkan prinsip hukum minimum. Para peneliti tersebut selanjutnya mengusulkan hukum minimum SprengelLiebig karena banyak doktrin yang ada dalam buku Liebig diyakini telah dipublikasi sebelumnya oleh Carl Sprengel.

Pemahaman mengenai hukum ini dapat dipermudah dengan melihat contoh pada bidang pertanian, misalnya pemupukan. Contoh yang mudah adalah kadar nitrogen $(\mathrm{N})$ dalam tanah. Dalam kadar minimum, tumbuhan tidak akan dapat berkembang dengan baik. Oleh karena itu, penambahan nitrogen ke substrat tumbuh dapat memberikan kondisi pertumbuhan yang lebih optimal (Setiadi dan Tjondronegoro, 1989).

\section{Perkembangan Sains: Apa yang Terjadi pada periode Pasca Liebig?}

Seiring dengan perkembangan zaman, tidak hanya unsur hara saja yang menjadi faktor pembatas minimum untuk pertumbuhan tanaman. Seiring dengan perkembangan ilmu pengetahuan, faktor-faktor ekologis lain seperti suhu (Odum, 1975; Setiadi dan Tjondronegoro 1989). Odum (1975) memberikan sebuah ulasan singkat terkait hukum ini dalam pembahasannya terkait faktor pembatas dalam tumbuhan.

Peneliti-peneliti selanjutnya menyimpulkan bahwa hukum minimum Liebig terkadang tidak berlaku sepenuhnya pada tumbuhan, yang terkadang disebut juga sebagai kelemahan hukum minimum Liebig. Terkait dengan hal ini, maka tumbuhan sebenarnya tidak hanya memiliki faktor pertumbuhan pada kondisi minimum saja, namun juga ketika faktor tersebut berada dalam jumlah yang berlebih (Odum, 1975; Setiadi dan Tjondronegoro, 1989). Salah satu contoh yang dapat diambil dari studi kontemporer untuk hal ini adalah Streck (2004). Peneliti tersebut merangkum hasil penelitian bahwa terdapat batas minimum dan maksimum pada pengaruh suhu terhadap vernalisasi Triticum aestivum, tingkat perkecambahan biji jagung (Zea mays) dan kemunculan daun serta pemanjangan daun Saintpaulia ionantha.

Hal tersebut menunjukkan bahwa hukum minimum Liebig menekankan pandangan untuk kondisi sumber daya pada jumlah minimumnya. Artinya, ketika kondisi berlebih belum dapat dijelaskan dengan hukum ini dan belum dapat menjelaskan mengapa ketika suatu faktor sumber daya pada tumbuhan tersedia dalam jumlah berlebih, pertumbuhan juga akan terhambat (Setiadi dan Tjondronegoro, 1989). Selain itu, peneliti pasca Liebig juga mengungkapkan bahwa faktor pembatas minimum ini juga saling berinteraksi (Odum, 1975). Dan penggambaran mudah untuk hal ini dapat ditemukan pada kaitan antara $\mathrm{pH}$ dan kadar nutrien dalam suatu habitat, misalnya kadar $\mathrm{Ca}, \mathrm{Mg}$, dan $\mathrm{K}$ yang rendah pada $\mathrm{pH}$ rendah (Townsend et al., 2008) .Interaksi ini menyebabkan adanya multiplikasi pada tiap tiap faktor minimum. Supaya tumbuhan dapat tumbuh optimum, pada faktanya semua faktor pembatas harus dihilangkan, tidak 
hanya satu faktor saja. Sebagai contoh, penambahan nutrien bersamaan dapat melipatkan hasil produksi jeruk (Wallace, 2012).

Setelah lebih dari seratus tahun, penelitian-penelitian yang mencoba mengkritisi atau memberikan sedikit pandangan berbeda dari hukum minimum Liebig juga ditemukan, misalnya Gorban et al. (2011). Para peneliti tersebut mengatakan bahwa hukum minimum adalah suatu paradoks. Mereka lebih lanjut menyimpulkan bahwa hukum minimum Liebig akan bekerja pada ekosistem yang konstan (fixed), sedangkan pada ekosistem yang terdapat proses adaptasi, sedikit menyimpang dari prinsip hukum minimum.

\section{Hukum Minimum dan Biologi Masa Kini: Contoh Aplikasi}

Implikasi dari pengetahuan mengenai hukum minimum telah menjadi komponen penting dalam berbagai bidang ilmu biologi kontemporer. Berikut akan disajikan beberapa uraian implikasi hukum tersebut pada empat bidang biologi masa kini, yaitu biologi evolusi, konservasi, ekologi indikator dan penanganan permasalahan lingkungan global.

Pertama, dalam bidang evolusi, sebuah studi oleh Warsi dan Dykhuizen (2017) berhasil mengungkapkan fakta bahwa dalam kondisi faktor ekologis, yaitu nutrien dalam keadaan minimum, satu nutrien yang paling rendah kadarnya menentukan respon populasi. Hal ini adalah prinsip dasar hukum minimum Liebig yang bekerja pada tingkatan di atas spesies. Akan tetapi, hal ini hanya berlaku untuk periode jangka pendek. Untuk sampai proses evolusi pada makhluk hidup, hal ini belum cukup, namun harus ada interaksi antar faktor yang sama-sama minimum atau disebut kolimitasi. Pernyataan terakhir tersebut, merupakan penjabaran dari hukum minimum versi Mitterlich (Wallace, 2012). Meski demikian, tetap pemahaman mengenai faktor minimum mana yang bekerja pada periode waktu tertentu adalah hal yang krusial.

Proses pembentukan spesies yang terbatas pada habitat tertentu, seperti kapur, mungkin merupakan hasil dari proses yang dijabarkan oleh Warsi dan Dykhuizen (2017). Ekosistem kapur merupakan salah satu ekosistem yang dapat ditemukan di Indonesia (Clements et al., 2006). Berbagai spesies tumbuhan banyak sekali yang hanya ditemukan di habitat ini, misalnya berbagai spesies anggrek kasut (Paphiopedilum spp.) dan Impatiens spp. (Vermeulen dan Whitten, 1999). Dugaan kuat, spesies nenek moyang mereka dulu beradaptasi dengan habitat baru, yang salah satunya dicirikan dengan rendahnya kadar air (Hughes et al., 2012) atau mungkin juga nutrien tertentu, misalnya alkali, sebagaimana telah menjadi latar belakang dasar pemikiran Liebig (von Liebig dan Playfair, 1840).

Kedua, aplikasi hukum minimum Liebig lainnya dapat ditemukan pada upaya konservasi spesies. Contoh penggunaan konsep hukum minimum dalam konservasi spesies dapat dilihat pada penelitian Linares (2013), yakni dalam upaya konservasi Taxus baccata (Taxaceae). Salah satu faktor penting yang diperhatikan dalam upaya konservasi spesies tersebut adalah kadar air pada area tertentu. Hal ini disebabkan karena ketersediaan air yang terbatas menjadi salah satu faktor pembatas regenerasi (Sanz et al., 2009). Ketika secara alami populasi tersebut diperkirakan tidak dapat hidup, maka upaya buatan pun tampaknya dapat dilakukan untuk meningkatkan kadar air dalam habitat spesies tersebut.

Ketiga, hukum minimum Liebig tampaknya dapat menjadi salah satu komponen penting dalam ekologi indikator karena mungkin mengindikasikan adanya faktor tertentu yang terbatas dalam lingkungan, yang lebih terbatas kepada ekosistem yang telah diketahui dengan baik. Hal ini tidak dapat berlaku pada ekosistem yang kurang diketahui seperti hutan hujan tropis. Meskipun demikian, konsep ini merupakan komponen penting yang menjelaskan kelimpahan suatu spesies yang dapat diturunkan ke dalam indeks diversitas. Indeks inilah yang berperan secara langsung sebagai indikator ekologis (Hiddink dan Kaiser, 2005)

Terakhir, baru-baru ini, penelitian mengenai rekonstruksi iklim telah dilakukan oleh Stine dan Huybers (2017). Kedua peneliti tersebut menggunakan lingkaran tahun untuk mengetahui adanya faktor pembatas minimum lingkungan. Mereka berhasil mengungkapkan bahwa pada tingkatan lokal, lingkaran tahun berkorelasi dengan perkembangan temperatur di bumi dan sejalan dengan hukum minimum Liebig. Meski studi ini belum sepenuhnya berhasil menggambarkan tujuannya, mereka mengatakan bahwa hukum minimum akan menjadi salah satu komponen penting ke depannya untuk menyelesaikan upaya 
rekonstruksi kondisi iklim di masa lalu. Hal ini akan menjadi dasar bagi mitigasi perubahan iklim ke depannya.

\section{Catatan penutup dan simpulan}

Dimunculkan oleh seorang ahli kimia organik, hukum minimum Liebig menjadi salah satu pondasi dalam ilmu ekologi hingga saat ini. Hukum ini terus menjadi dasar berbagai pandangan-pandangan dalam berbagai bidang ekologi. Contoh-contohnya pun dapat diamati dengan mudah di alam. Terlepas dari kekurangan dari hukum ini sendiri, hukum minimum akan selalu menjadi teori yang berguna dalam studi ekologi tumbuhan ke depannya.

\section{Ucapan Terima Kasih}

Penulis mengucapkan terima kasih kepada Ibnul Qayim, Institut Pertanian Bogor yang telah memberikan tanggapan terkait tulisan ini. Ucapan terima kasih juga penulis sampaikan kepada Eka Setiawan yang telah membaca dan menanggapi naskah awal.

\section{Daftar Pustaka}

Barak, P. (2000). Essential elements for plant growth: law of the minimum. [online] (https://soils.wisc.edu/facstaff/barak/soilscience326/lawofmin.htm), [diakses tanggal 18 Februari 2018].

Begon, M., Townsend, C. R., \& Harper, J. L. (2006). Ecology: from individuals to ecosystems. Malden, USA: Blackwell Publishing.

Clements, R., Sodhi, N. S., Schilthuizen, M., \& Ng, P. K. (2006). Limestone karsts of Southeast Asia: imperiled arks of biodiversity. Bioscience, 56(9), 733-742.

Gorban, A. N., Pokidysheva, L. I., Smirnova, E. V., \& Tyukina, T. A. (2011). Law of the minimum paradoxes. Bulletin of mathematical biology, 73(9), 2013-2044.

Hughes, M., Girmansyah, D., Handoyo, W. A., Puglisi, C. (2012). The limestone flora of Sumatra. Gardenwise, 39, 18-21.

Linares, J. C. (2013). Shifting limiting factors for population dynamics and conservation status of the endangered English yew (Taxus baccata L., Taxaceae). Forest Ecology and Management, 291, 119127.

Odum, E. P. (1975). Ecology Ecology, the link between the natural and the social sciences (Modern biology series). New York, USA: Holt, Rinehart and Winston.

Sanz, R., Pulido, F., \& Nogués - Bravo, D. (2009). Predicting mechanisms across scales: amplified effects of abiotic constraints on the recruitment of yew Taxus baccata. Ecography, 32(6), 993-1000.

Setiadi, D., \& Tjondronegoro, P. D. (1989). Dasar-dasar ekologi. Bogor, Indonesia: Departemen Pendidikan dan Kebudayaan Direktorat Jenderal Pendidikan Tinggi Pusat Antar Universitas Ilmu Hayat.

Stine, A. R., \& Huybers, P. (2017). Implications of Liebig's law of the minimum for tree-ring reconstructions of climate. Environmental Research Letters, 12(11), 114018.

Streck, N. A. (2004). A temperature response function for modeling leaf growth and development of the African violet (Saintpaulia ionantha Wendl.). Ciência Rural, 34(1), 55-62.

Townsend, C. R., Begon, M., \& Harper, J. L. (2008). Essentials of Ecology (3rd edition). Massachusetts, USA: Blackwell Publishing.

van der Ploeg, R. R., \& Kirkham, M. B. (1999). On the origin of the theory of mineral nutrition of plants and the law of the minimum. Soil Science Society of America Journal, 63(5), 1055-1062. 
Vermeulen, J., \& Whitten, T. (1999). Biodiversity and cultural property in the management of limestone resources: lessons from East Asia. Washington, D.C., USA: The World Bank.

von Liebig, J. F. (1841). Die organische Chemie in ihrer Anwendung auf Agricultur und Physiologie. Braunschweig, Germany: F. Vieweg.

Von Liebig, J.F. dan L. Playfair. (1840). Organic chemistry in its applications to agriculture and physiology. London, UK: Taylor and Walton.

Wallace, A. (1993). The law of the maximum. Better crops, 77(2), 20-22.

Warsi, O. M., \& Dykhuizen, D. E. (2017). Evolutionary implications of Liebig's law of the minimum: selection under low concentrations of two nonsubstitutable nutrients. Ecology and evolution, 7(14), 5296-5309. 